
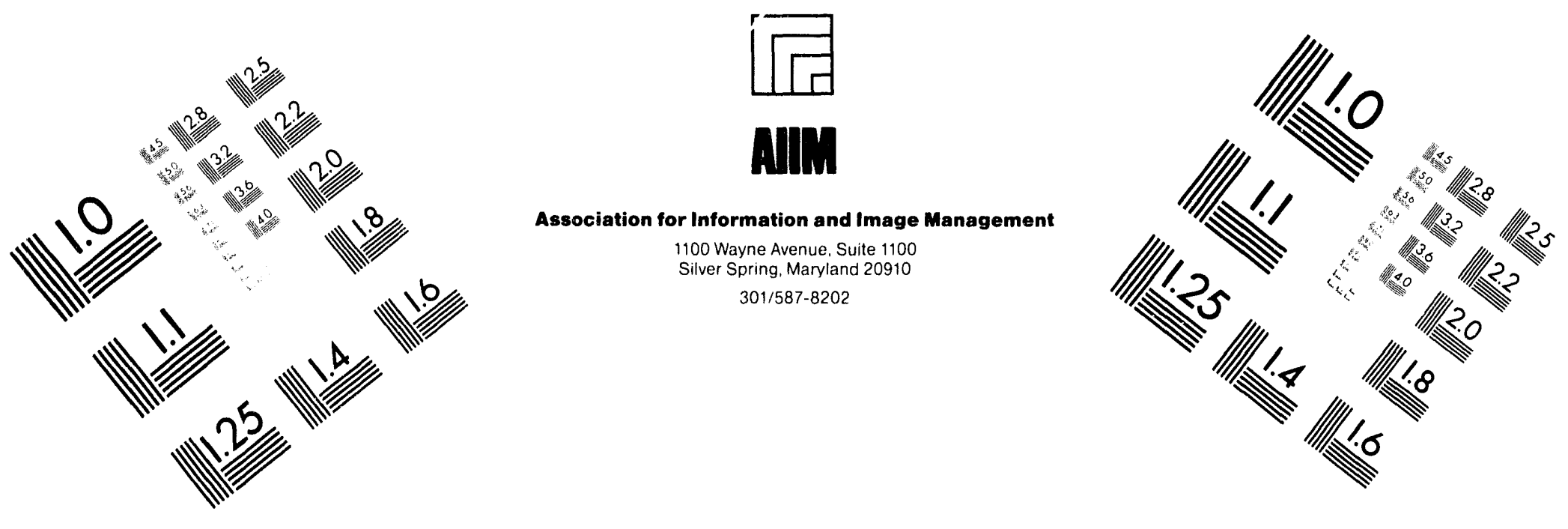

\title{
Centimeter
}

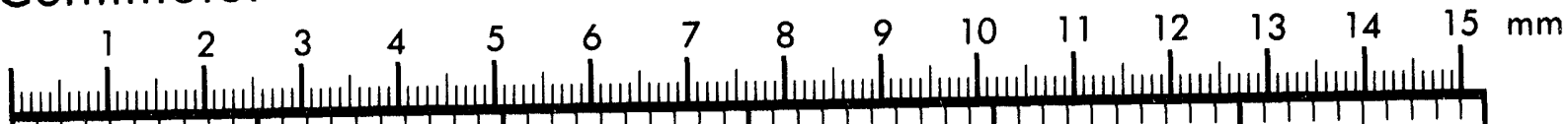

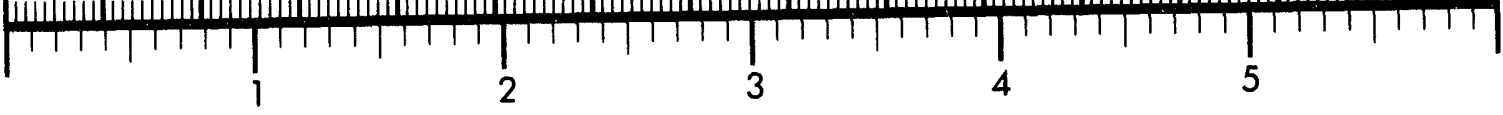
Inches
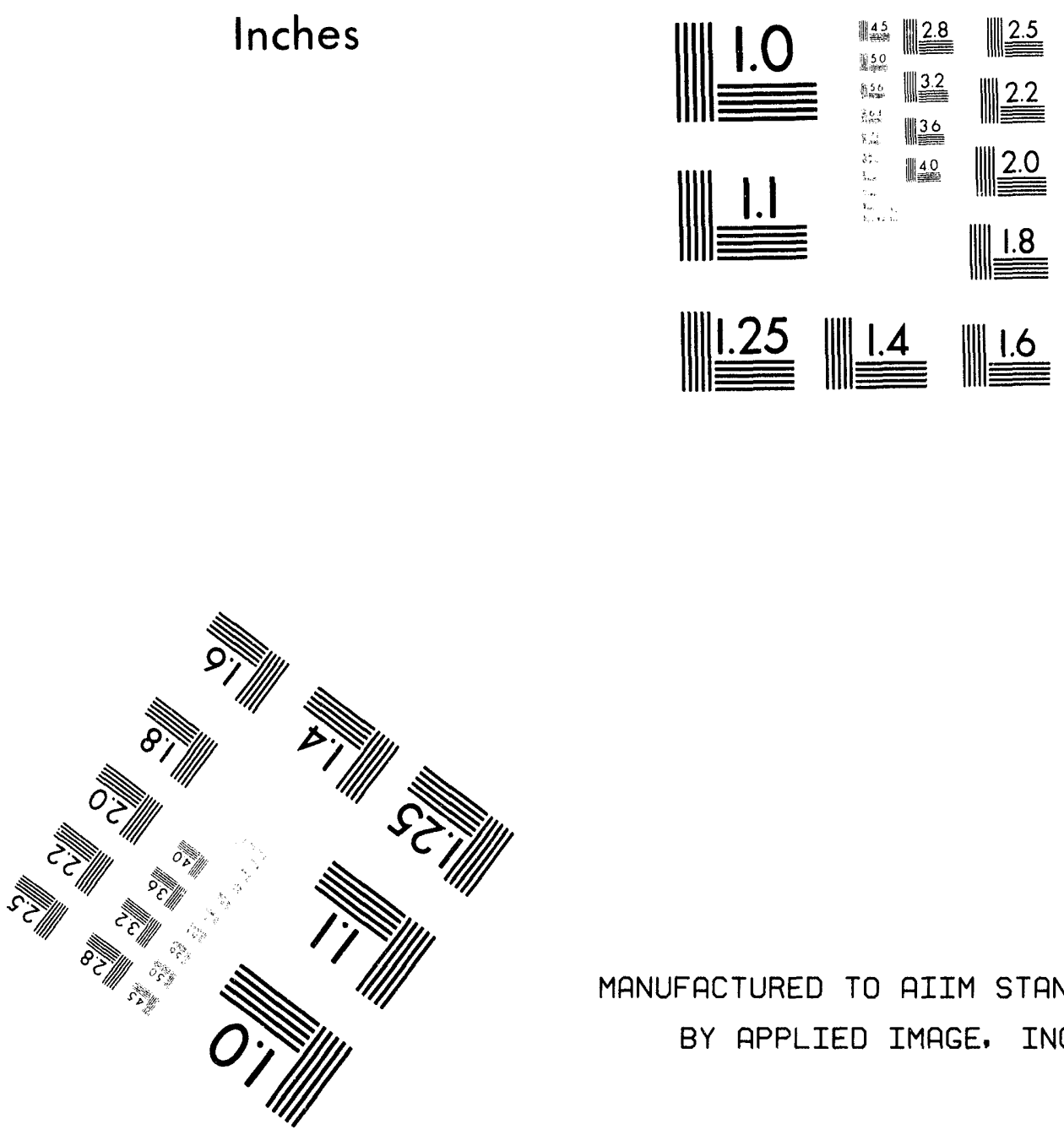

MANUFACTURED TO AIIM STANDARDS BY APPLIED IMAGE, INC.

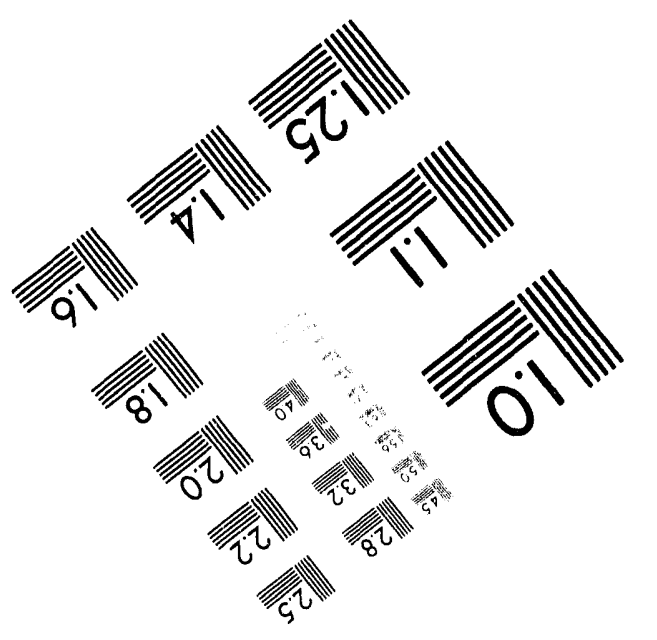



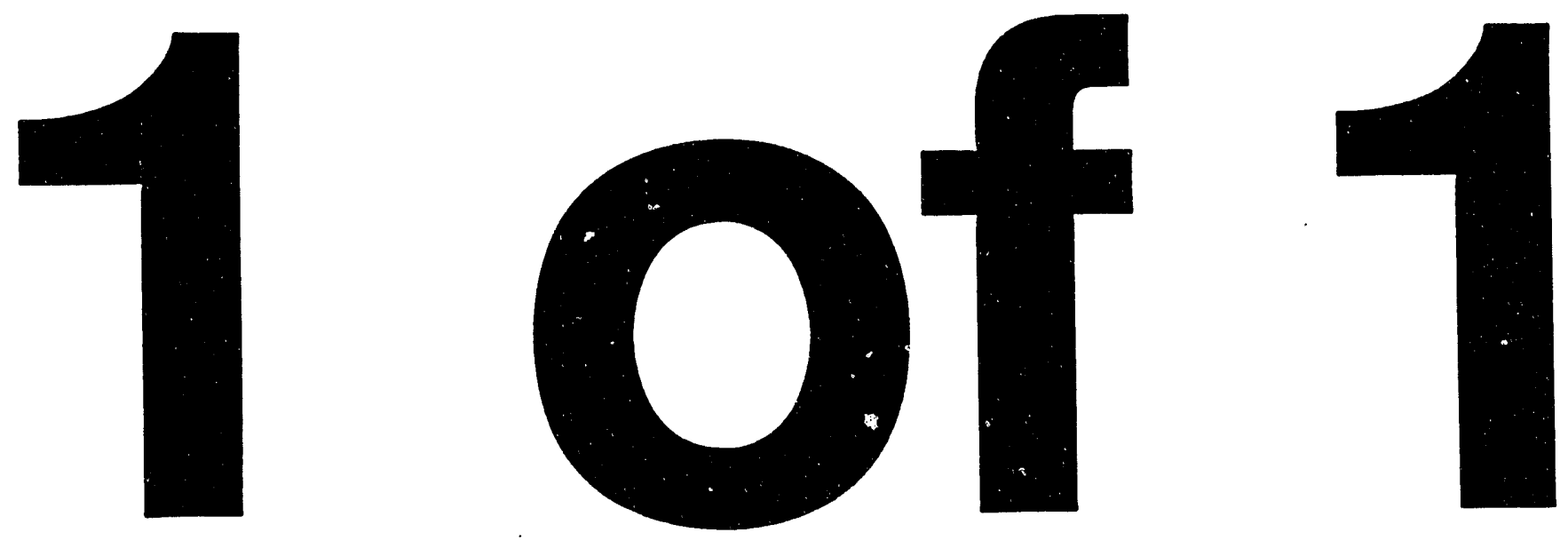


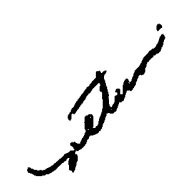

\section{censimatrow DECLLSSIFIED}

\section{GENERAL ELECTRIC}

HANFORD ATOMIC PRODUCTS OPERATION - RICHLAND, WASHINGTON

DOCUMENT NO.

HW -80168
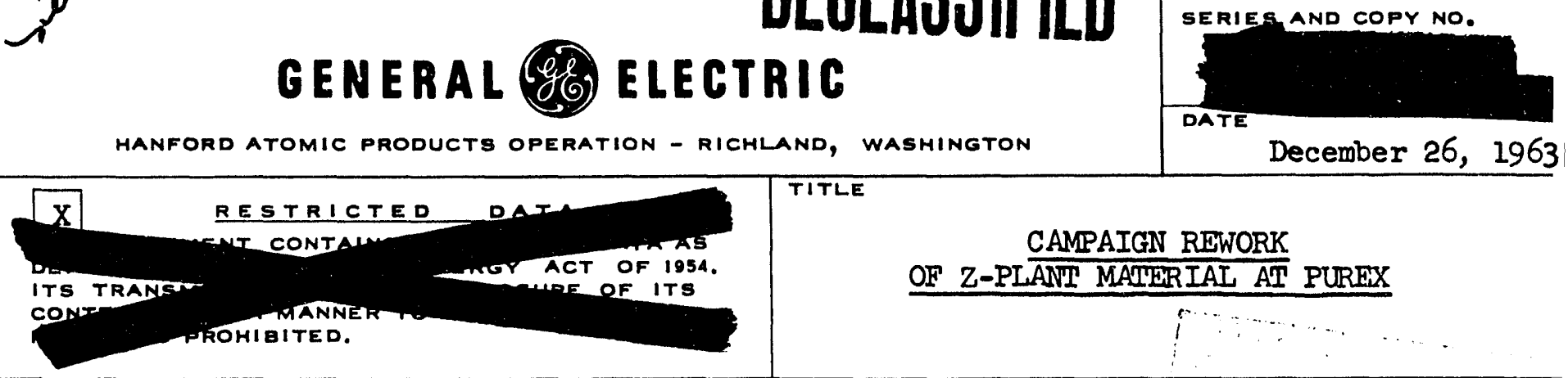

OTHER OFFICIAL CLASSIFIED INFORMATION

THIS MATERIAL CONTAINS INFORMATION AFFECTING THE NATIONAL DEFENSE OF THE UNITED STATES WITHIN THE MEANING OF THE ESPIONAGE LAWS, TITLE 18, U. S.C., SECS. 793 AND 794, THE TRANSMISSION OR REVELATION OF WHICH IN ANY MANNER TO AN UNAUTHORIZED PERSON IS PROHIBITED BY LAW.

TITLE

\section{CAMPAIGN REWORK \\ OF Z-PIANI MATERIAL AT PUREX}

AUTHOR

B. F. Judson

and

J. B. Kendall

THIS DOCUMENT TO IT. WHEN GUARDED

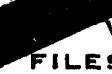
CLAO IET IS YOW

NUECT AND FROM

RESIDENCE IS PRO SBTAIN THEM FRO TO SIGN IN THE.

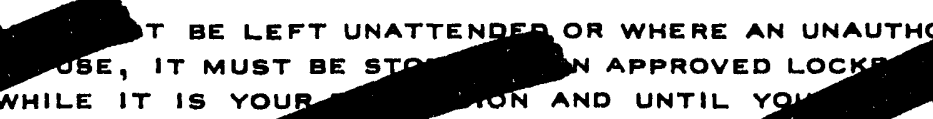
IN APPROVED LOCKP ASIBILITY TO KEEP TTS contents WITH ISSUING FILE THORIZED PERSON
IT IS NOT TO BE RELATED ISSUING FILE - PROVIDED BELOW. UTE TO: PAYROLL NO. CATED. IF ADDITION
SERSONS READING THIS e

FILESTROUTE


This document consists of

\section{7 pages.}

Distribution:

1. 0. F. Beaulieu

2. T. P. Duckworth

3. J.W. Fillmore

4. W. S. Frank

5. W. T. Gartin

6. W. M. Harty

7. B. F. Judson

8. J. B. Kendall

9-10. R.W. McCullugh

11. R.J. Sloat

12. A. J. Waligura

13. T. H. Warren

14. 300 File

15. Record File

CAMPAIGN REWORK

OF Z-PLALI MATERIAL AT PUREXX

By

B. F. Judson and J. B. Kendall

Purex Process Englneering

Research and Engineering

Chemical Processing Department

December 26, 1963

HANFORD ATOMTC PRODUCTS OPERATION RICHLAND, WASHINGTON

Work performed under Contract \#Anr(45-1)-1350

between the Atomic Energy Commission and the General Electric Company

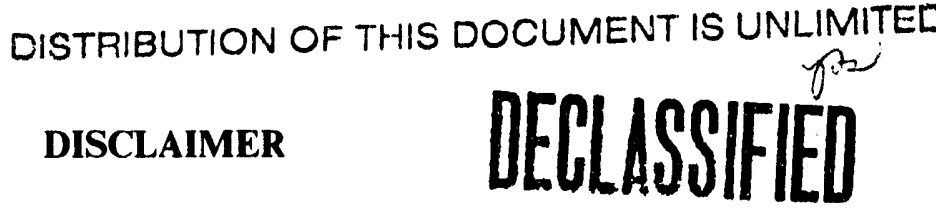

This report was prepared as an account of work sponsored by an agency of the United States Government. Neither the United States Government nor any agency thereof, nor any of their

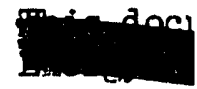
contents

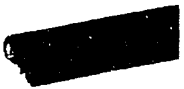
employees, makes any warranty, express or implied, or assumes any legal liability or responsibility for the accuracy, completeness, or usefulness of any information, apparatus, product, or process disclosed, or represents that its use would not infringe privately owned rights. Reference herein to any specific commercial product, process, or service by trade name, trademark, manufacturer, or otherwise does not necessarily constitute or imply its endorsement, recommendation, or favoring by the United States Government or any agency thereof. The views and opinions of authors expressed herein do not necessarily state or reflect those of the United States Government or any agency thereof. 
December 26, 1963

R. W. Mecullugh, Manager

Furex Frocessing

Purex Cperation

OF Z-PL ANI MATTERIAL AI FUREX

Introduction and Srmery

The Purex Flant has been requested to Frocess ZmIant MR and EPI solutions conw taining about $200 \mathrm{kilog} r \mathrm{~ms}$ of plutonium in order to alleviate processing problems at Z-Plant and to reduce the imventory of MR and EPT rework. Campaign recycle of uranium through the main plant is recommended as an economical and effective means of reworking lisge quantities of Z-Flent plutonium solutions. The following memow randum outlines frocess alternates and costs for reworking the solutions and itemizes specific recomendations for process and critical mass control.

\section{Zo-Plant Rework Solutions}

The ZaPlant plutonium solutions that are scheduled for campaign rework through the Purex Plant are commonly called. EPT and MR Rework. The EPP solution is the product. from their Plutonium Ion Exshange unit. This solution is about 30 a 60 grams per liter of plutonium in 80.7 to $1.3 \mathrm{M}_{3} \mathrm{HW}_{3}$ medium. EFT solutions may also contain a trace of resin fines. The $M R$ rework solution is the product of plutonium scrap dissolutions. The MR solution will very from 4.0 to 150 grams of pilutonium per liter in a highly corrosive 10 to $15 \mathrm{M} \mathrm{EN3}, 0.1$ to $0.3 \mathrm{M} \mathrm{F}$, and 0.1 to $0.3 \mathrm{M} \mathrm{Al}$ media. In addition, the MR rework solution may contain an alloy agent that is 1.0 welght per cent of the plutonium. Some of the MR rework solution may contain an sppreciable quantity of post-precipitated aluminum nitrate crystals. whe solutions normally do not cuntaln organic phases, plutonium solids, or other materiels that are deletericus to the Furex process, although some irsoluble plutorinu and other substances have been noted.

\section{Process Alteruates end Cost.8}

Plutonium process rates in the Purex Plent are presently limited by the XCF. Concentrator capacity to ebout 25 kllograms per day. Although critical mass sfecifications permit a plutonium concentration of 1500 grams per ton of uranium in the First Decuntamination Cycle, experlence has shown that the feed (EAT) to the system must be generally limited to about $1000 \mathrm{~g} / \mathrm{T}$ because of normal backcyele flutonfum via the IBSU and 3 WS streams and because frocess upsets can quickly increase the plutonium recycle via the $3 W B$ stream to the First Decontamination Gycle. Sin the basis of $1000 \mathrm{~g} / \mathrm{m}$ and a dissolver solution of $600 \mathrm{~g} / \mathrm{T}$, the maximum rework rate is $400 \mathrm{~g} / \mathrm{m}$. Since the naximum plutonium processing rate is $25 \mathrm{kllograms}$ per day, the maximum rate of plutonium rework

is 10 kilograms and occurs when the uranium processing rate is 25 tons per day of dissolver feed. Incressing the processing rate of dissolver solution beyond 25 tons of uranium per day requires a reduction in the rate of filutonium rework sirice the grams of plutionfin per ton of uranium must be reduced to prevent ex. ceeding the 25 kilogrems fer day limit of the XOF ioncentrator.

Reworking flutontum at: a rate beyond 10 kilograms per day requires either the recycle of "cold" uranium or an increase in the grams of plutonium per ton of 
urenium above $1000 \mathrm{~g} / \mathrm{T}$ while decreasing the plant rate for dissolver solutions so that the total plutonium processing rate does not exceed 25 kilograms per day. Although reducing the plant rate and increasing the $\mathrm{g} / \mathrm{I}$ would minimize plutonium rework costs, it is preferable to recycle "cold" uranium in order to maintain stable critical mass control.

The recycle of "cold" uranium increases the cost of reworking plutonium since the First Decontamination Cycle costs of processing the "cold" uranium must be charged completely to the plutonium product. "Cold" uranium that does not meet final product specifications and requires rework can be used as the uranium recycle but this method of uranium recycle does not change the plutonium processing costs because the off-specifleation uranium processing costs are not changed. In other words, the uranium still requires processing through the Second Uranium Cycle and this is all it required initially. On the other hand, since the uranium and plutonium costs are not increased by recycling "cold" off-specification uranium product, there is no reason not to recycle of $f$ specification uranium unless the plant process routings required are expensive.

Based on $1000 \mathrm{~g} / \mathrm{T}$ per ton of "cold" uranium and assuming the uranium is not processed through the Second Uranium Cycle, the essential material costs for reworking plutionium is about $\$ 90$ per kilogram. Overall rework rates are limited to somewhat less than $25 \mathrm{Kg} /$ day by con handing rates as discussed below.

An alterate methos of reworking plutonium is direct addition to the Flutonium Ion Exchange and processing only enough "cold" uranium through the plant for critical mass control of the plutonium recycled via the $3 \mathrm{WB}$ stream. The essential material costs associated with reworking plutonium in this manner would be reduced. However, because reworking $M R$ plutonium in $N G C e l l$ requires plutonium valence and other feed adjustment steps in very limited facilities, the rate of plutonium rework is less than $6 \mathrm{Kg} /$ day, which is undesirably low for the large rework campaign planneã.

\section{Rework joad-Ia Stations}

Plutonium rework solutions can be added to process streams in the Purex Plant from either the PR Room or the RC Recycle Hood. The RC Recycle Food adds the plutonium rework solutions only to TK-E6 (BAF), while the PR Room can add the plutonium rework solutions to either TK-NI (XAF') or TK-E6 (HAF'). Addition from the FR Rosm to TK NI (XAF) is rarely used because of the time consuming and complicated feed adjusted requirements before Plutonium Ion Exchange processing.

The E-CEll Sump critical mass control specifications limits the plutonium con. centration to 75 grems fer liter(1). For this reason, plutonium rework solutions greater than 75 grams per liter shall not be added to TK-E 6 from either the RC Recycle Hood or the PR Room. However, since the TK-LIl toTK-E6 transfer jet dilutes the IIl solution about three-fold, plutonium at concentrations of up to 225 grams per liter can be transferred from TK-Lll.

(1) HW-71625 (Secret), "Process Specifications for Critical Mass Control w Purex Plant (Revlision No. 3)", B. F. Judson and G. C. Oberg, October 15, 1962. 
Rework gaiftions through the sample gillery Ioal-in Station should enter IK.E6 directly from the product transfer can. The RC Recycle Storage Tank in the simple gillery is ifmited to a plutonium mass of 650 grams, corresponding to a maximum plutonium concentration of 13 grams per liter and thus is not suit. able for rework operations.

The critical mass control specifications require that both TK-E6 agitators are operating before plutonium rework solutions are added. The TK-III to MK-E6 traxsfer jet is interlooked with the agitators to prevent transfers when the TKK.E6 agitators are not operating. Administrative controls, however, are required for transfers from the samle gallery Logdin Station to Wr-EG.

In adaition, the critical mass control specifications requires that no plutonium rework solution shall be added unless $\mathrm{TH}$ KE 6 is at least half full and the TK-E6 aciaitiy is at least $0.4 \mathrm{M}$.

\section{Can Ioad-In Rates}

The maximum processing ryte for plutonium in Purex is limited to 25 kilograms per day by the XISP Concentrator. The overall rate of reworking plutonium, however, may be Ilmited to a lower value by can handiling limitations in the rework load-in facilities. It is estimated that the RC Recycle Hocd con handle about 40 cans per day, and the PR Room can handle from 9 to 15 cans fer day depeniling on the rate of plutonium losi-out requirements. However, the FR Room can probably ouly hanale 6 cans per day, if the rework solution is trested for frocessing in the Flutonium Ion Exctiange unit. Basea on these maximum number of cans, the maximum normal load-in rates from the $\mathrm{R}$ ( Recycle Hood to $\mathrm{MK}$ - $\mathrm{E} 6$, from the PR Room to TH-E6, and from the PR Room to TK-NI are about 20, 9 to 15, and $6 \mathrm{Kgs}$ of plutonium per day. Since many of the cars will not be as concertrated as desired, the maximum rework rates probably cannot be routinely achleved.

However, the Purex Plant should be able to attain a total rework rate via TK-E6 approsching the Furex Plant processing limit by locding in plutonium from both the FR Room and the RC Recycle Hood. Since the loadwin rate via the FR Room is only 9 to $15 \mathrm{kllograms}$ per day, the RC Recycle jood load in rate roust be 10 to 16 kilograms to attain the maximum Purex plutonium processing rate. This means that at least half and preferably seventy per cent of the plutorium rework should be in solutions less than 75 grams per liter to use the RC Recycle losd in station effectively and thus attain the maximum rate of plutonium rework. A verbel sgreement has been reached with Z-Plant to dilute the MR rework to less than 75 grams per liter as soon as sufficient FK cans are available. Sufficlent cans should be avallable soon after the Purex flant starts the plitionlum rework campaign.

Since it is desirsble to operate at the maxim of $1000 \mathrm{~g} / \mathrm{m}$ to minimize essen tial material cuts, and since operation of the Furex Plant at a plutionium processing rate of 25 kilograms per day is sensitive to process upsets and critical mass control problems, an initial uranium processing rate of 20 tons per day is recommended. After the losd-in procedures and process conditions are established, an increase in the uranium processing rate to 25 tons per day may he warranted. On the basis of 20 tons of uranium per day and a $1000 \mathrm{~g} / \mathrm{I}$ pilutonium concentratior, a 200 kilogram campeign will require 10 days of plant operation. 
The ZwPlant dissolvers have a capacity of gbout 15 kilograms per day. Since the quantity of plutonfim already in solution is in excess of 50 kilograms, the Furex Flant processing rate should not be limited by the Z-Flant dissolvers duriag the $200 \mathrm{kilogram}$ compalgn.

\section{Frocess Recommendatious}

The following recomendations are suggestal for frocessing Z-Plant MR and EPol solutions while recycling flutoniumofree uranium (itims marked with an asterisk are required by Critical Mass ontrol specifications(I):

\section{A. Rework ife tise Fi Recycle Jooa}

1. No rework solutions greater than 75 grams per liter shall be added to TK-E6 via the RC Recycle Hood.* Flutonium solids with a particle size ereater than 40 microns shall not be introduced into the Furex Plant.*

2. Rework solutions should be added directly to TK-E:6 througt a < 40 micron f'llter. We Recycle Storage Tank should be blanked a $f^{\prime \prime} f^{\circ}$ to prevent uncontrolled additions.*

3. No IR cans contalring more than 600 grams will be added to wiK 6 from the RC kecycle Food. Each $P R$ can will be checked with the neutron monitor to verify the quantity of plutonium is less than 600 grams.

4. Each FR can should be thoroughly flushed with a dilute nitric solution. Before filling with Furex plutionium product, the car sho:ald also be inspected to assure that an appreciable quantitiy of solids is sot present. If solids are present, the can should. be returned to $Z$-Fisnt for additioral flushing.

5. As gart of the campaign's special administrative controls, a light ani/or slerm system should be provided at the RG Recycle Eood to assure that plutionium solutions are not added to $\mathrm{TK}=\mathrm{E} 6$ without. $T K-E 5$ agitators operating. Cperation of $T \mathrm{~K}-\mathrm{E} 6$ agitators is requirea by Ref. I.

3. Rework Via tibe FR Room

1. Rework solutions greater twen 75 grams fer liter shall be gaded via the Fr Rocm. Flutionium solias with a particle size greater than 40 mfcrons shall not be introduced into the Furex Flant.*

2. The rework solution should be transferred from the PF can to IK-I $9 / I_{10}$ through a less than 40 micron filter to prevent ilugging PR Room lines and valves.

3. The rework solution should be diluted with a nitric asid solution. The nitric acia solution for dilution must be $\pm 2.0 \mathrm{M} \mathrm{HNC} 3$ in TK. I9/I10 to prevert exceeling 225 grams per liter.* The allution stiould slso assure that the acidity of the final solution will be $\leqslant 10 \mathrm{M} . \mathrm{MY}_{3}$ to prevent precipitation of aluminum nitrate. 
4. Each $2 R$ can should be thoroughly flushed with a dilute nitric solution. Eefore loading with Purex plutonium product, the can should also be inspected to assure that an appreciable quantity of solids is not present. If solids are present, the can should be returned to $\mathrm{Z}-\mathrm{Pla}$ t for additional flushing.

5. Only one plutonium storage tank, L9 or I.10, should be used for handling rework. In addition, the tank should be isolated by installation of appropriate line blanks to prevent a violation of critical mass control or contamination of the Furex plutonium product.

6. TK.IIl should not contain more than 5000 grams of plutonium.

7. The LIl to $\mathrm{E} 6$ pump should operate for several minutes after closing the suction valve on the I.II to $\mathrm{E} 6$ jet in order to flush the III to E6 line.

C. TK-E6 Flutonium and Nitric Concentration and Volume

1. Flutonium should not be added to $\mathrm{WK}$ E6 unless the TK $\mathrm{E} 6$ solution is greater than $0.5 \mathrm{M} \mathrm{HNO}_{3}$, thereby avoiding plutonium polymer formation.* The control of $\mathrm{m} K \mathrm{~K}-6$ acidity may be based on acid analysis of TK-KI or P2 area rework solutions.

2. TK-E6 must be at least half full before the addition of any plutonium rework solution.*

3. The Initial plutonium butt to TKaE6 should be limited to 750 grams per ton of uranium and should be made from only one station to guard against double batching. Each batch of TK=E6 after butting with plutonium should be samfled for mash Pu, HIOO3 and Sp.G. aralyses.

4. The WK $\mathrm{E} 6$ flutonium concentration should be limited to a maximum 1000 grams per ton and should be increased from the $750 \mathrm{~g} / \mathrm{T}$ only after a plutonium analysis of the initial TK-E6 plutonium butt. The secord butt of $M K-E 6$ should be made only from the RC Recycle Hood.

\section{Other Frocessing Recomendations}

1. One galion of $2.4 \mathrm{M}$ aluminum nitrate should be added for each ER can of MR rework solution upstream of the IWW Concentrator. Aluminum additions are not required for EPI solutions.

2. The recycle uranium route should be TK-E6 to TK-D5 to TK-HI to provide adequate lag storgge of feed solution.

3. Fumank rework uranium should not be added via TK-K6 to prevent contamination of uranium product.

4. The Second Uranium Cycle should not be operated unless the Parank uranium rework is being processed. This is required to minimize essential material costs. 


\section{$\rightarrow$ rTLLLASSFIED}

HW -80168

5. Uranium recycled from TK-KI to TK-E6 should be screened to prevent $\mathrm{TK}-\mathrm{K}$ solids from belng added to other processing vessels.

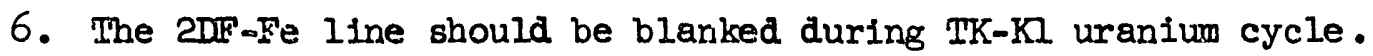
Any TK-KI recycle solution containing ferrous sulfamate should be destroyed with sodium nitrite. The recomended concentration of excess sodium nitrite is $0.01 \underline{M}$.

7. During recycle of TK-KI uranium, the $2 \mathrm{DF}-\mathrm{HNO}_{3} \mathrm{fl}_{\mathrm{l}} \mathrm{W}$ should be shut off. Inis nitric acid loss to the $3 W B$ should be made up by the addition of Purex recovered acid to TK-Jl.

8. The HA Column saturation should be reduced during the rework campaign. Commensurate with decontamination and waste loss performance. However, the saturation should be maintained at a reasonable level to prevent a large increase in the HAP nitrite concentration.

Draft procedures and line routings prepared during the rework study are avallable for your use. We would be happy to be of any further assistance.

B Keudall

J.) B. Kendall

Purex Process Engineering

Research and Engineering

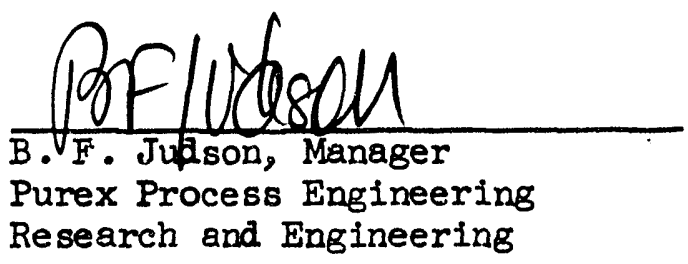

BF Judson:JBK: rm j 

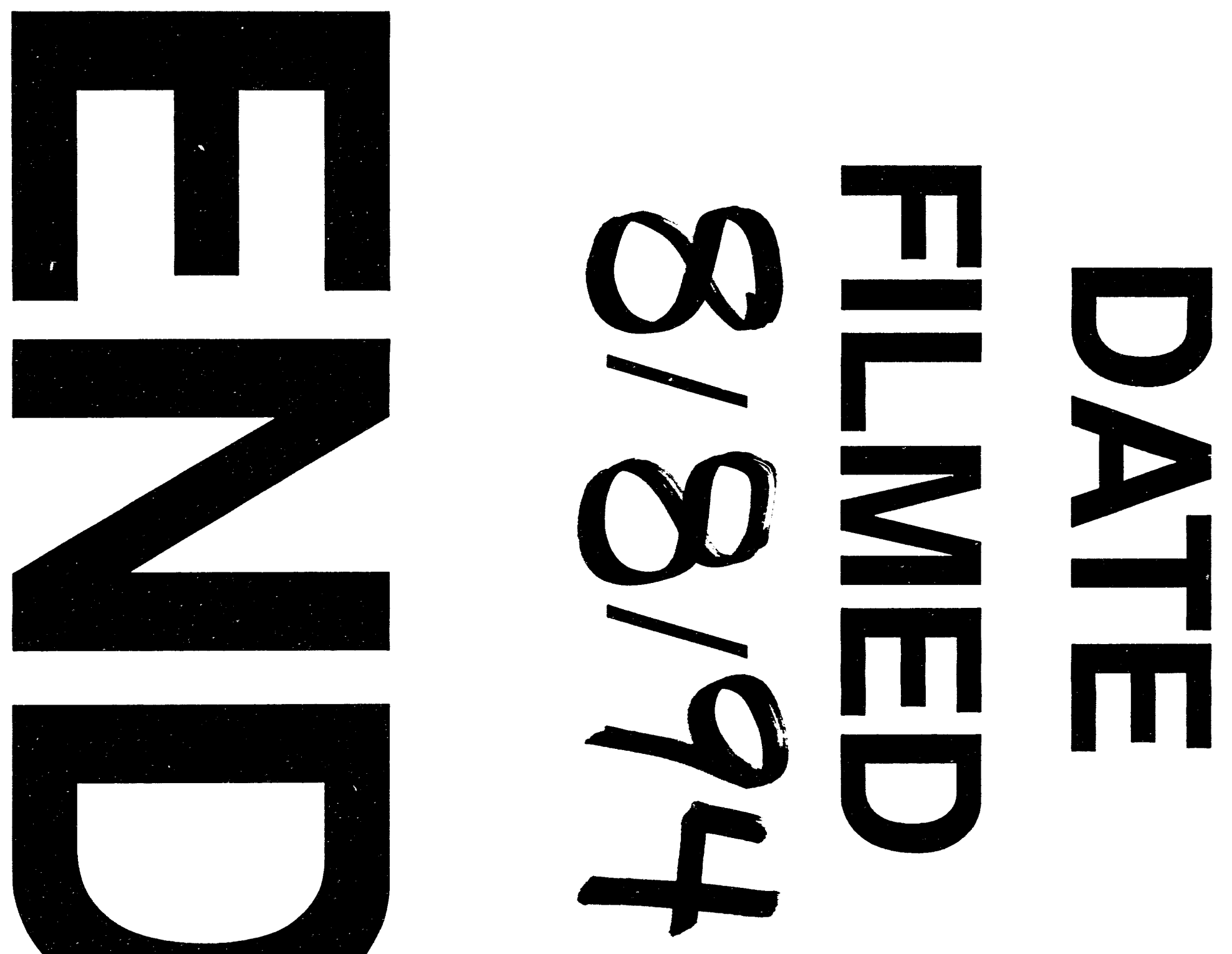

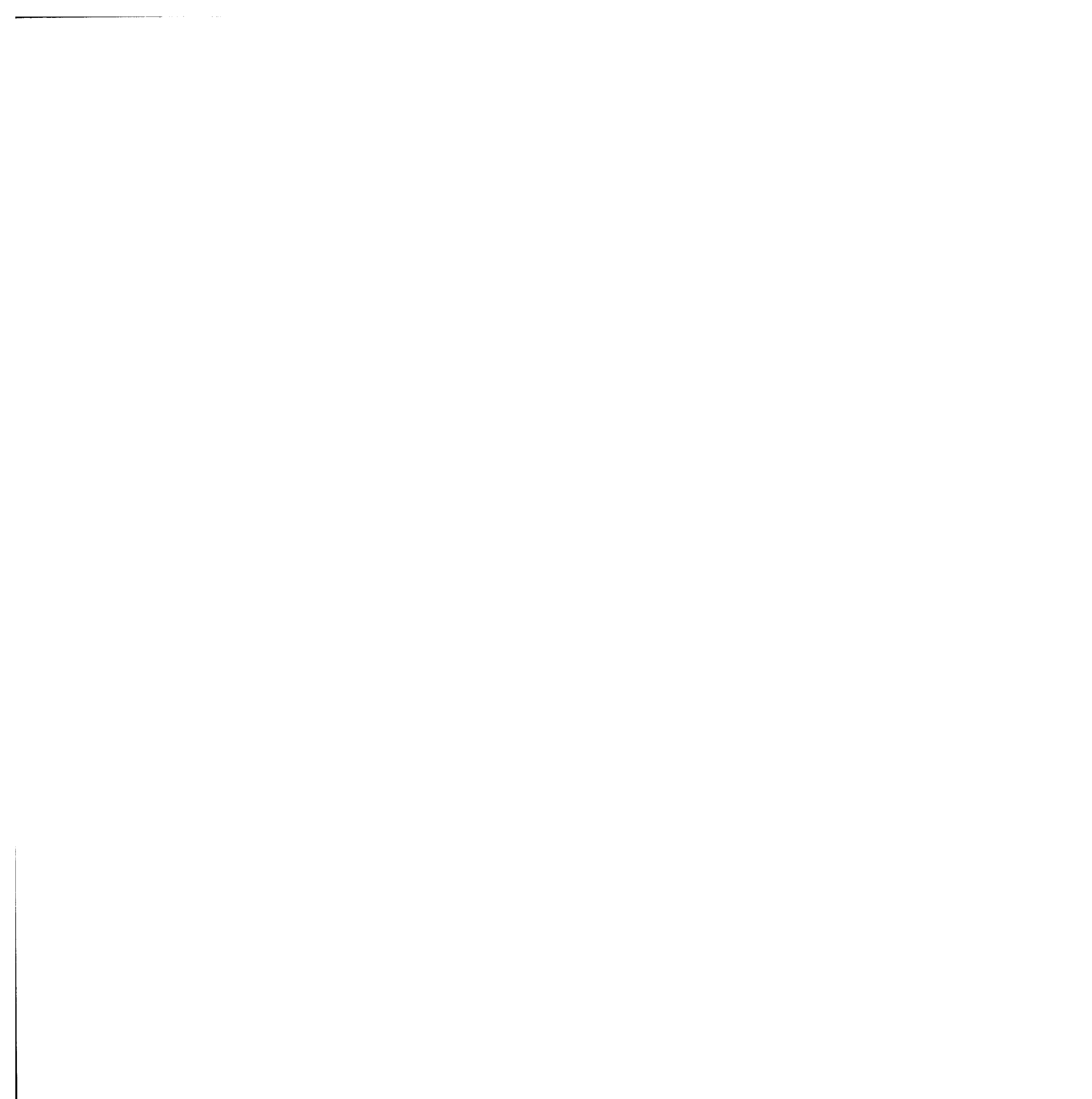